\title{
Allergic reaction to Dermabond in gynaecologic surgery
}

\author{
Justin Gorski $^{\mathbf{1}^{*}}$ and Linus Chuang ${ }^{2}$ \\ ${ }^{1}$ Department of Obstetrics, Gynaecology and Reproductive Science Icahn School of Medicine at Mount Sinai New York, New York, USA \\ ${ }^{2}$ Chairman, Department of Obstetrics and Gynaecology Western Connecticut Health Network, Danbury, CT, USA
}

\begin{abstract}
A 63-year-old female presented on post-operative day 7 status post total laparoscopic hysterectomy and bilateral salpingo-oophorectomy with sudden onset erythema and pruritus around all four port site incisions. Upon physical exam, a thin layer of Dermabond remained in place on the epidermis and an erythematous raised wheal (1-3 $\mathrm{cm}$ radius) surrounded each incision. The patient was advised to remove the skin adhesive with petroleum jelly and acetone. Dermatologist evaluation confirmed the suspicion of an allergic reaction to Dermabond and recommended application of a thin topical layer of hydrocortisone $1 \%$ to affected areas $2-4$ times per day. Skin inflammation and pruritus abated completely within 2 days. Confirmatory allergic patch testing performed three years after initial reaction was positive for ethyl cyanoacrylate.
\end{abstract}

Dermabond is a liquid topical skin adhesive containing a monomeric 2-octyl cyanoacrylate formulation and the colorant D\&C Violet \#2 which should slough off with desquamation of the epidermis 7-14 days after application. There has never been a reported case resulting from gynaecologic surgery until now.

\section{Introduction}

Laparoscopic and robotic hysterectomy are becoming increasingly popular alternatives to open abdominal procedures. Hysterectomy is one the most commonly performed surgeries in women in the United States. The number is still staggering even though some estimate that the number of hysterectomies has been steadily declining over the last decade from a peak of 681,234 performed in 2002 to 433,621 cases reported in 2010. This decline has been attributed to the introduction of minimally invasive techniques such as uterine artery embolization for the treatment of leiomyomata and non-surgical ablative therapies that are now commonly used for abnormal benign uterine bleeding [1]. However, it should be noted that these figures only include those patients requiring inpatient hospitalization and do not capture sameday surgery. Thus, the increasingly large number of hysterectomies being performed with traditional laparoscopic and robotically-assisted laparoscopic techniques may contribute to a gross underestimation of the actual number accomplished. In a cohort study of 264,758 women who underwent hysterectomy for benign gynaecologic disorders at 441 hospitals across the United States from 2007 to 2010, the use of robotically assisted hysterectomy increased from $0.5 \%$ in 2007 to $9.5 \%$ of all hysterectomies in 2010 and laparoscopic hysterectomy rates increased from $24.3 \%$ to $30.5 \%$ [2].

The increasing popularity of Dermabond in the gynaecologic operating room stems from its ease of use to close port site incisions at the end of laparoscopic surgery. Thus, allergic reactions should only increase as laparoscopic and robotically assisted hysterectomy replace open abdominal and vaginal techniques.

Dermabond is a liquid topical skin adhesive containing a monomeric 2-octyl cyanoacrylate formulation and the colorant D\&C Violet \#2 [3]. The use of Dermabond for surgical or traumatic wound closure was first approved in the United States by the FDA for human use in 1998. This addition is the most recent expansion of traditional skin wound closure techniques such as suture, staple, and adhesive tape approximation [4]. Dermabond has rapidly disseminated to nearly every surgical specialty due to the unique ease of use. The material is rapidly converted from a liquid to a solid state via polymerization at room temperature without the need for a catalyst, evaporation of a solvent or application of pressure [5]. Contact with anionic substances, such as blood, initiates the polymerization reaction and the material quickly sets to form a dry solid film that holds apposed skin edges together [6]. This polymerization is an exothermic reaction which may release significant heat [7].

Use of cyanoacrylates for adhesive applications dates to their initial synthesis and patent in 1949 [8]. The adhesive property of the compound methyl 2-cyanoacrylate was first described in the literature by H.W. Coover and was marketed by the Eastman Kodak Company in 1958 as formulation "Eastman 910" [9]. The substance was used as an industrial adhesive for metal, glass, rubber, and plastics since its introduction and eventually gained popularity in households as Superglue. Medicinal use of cyanoacrylate adhesives before FDA approval dates to the Vietnam War where field surgeons regularly used the formulation to quickly stop haemorrhage from skin wounds [10]. Its medical use quickly spread and interestingly, the first reported use of a cyanoacrylate tissue adhesive on the human eye occurred in 1968 [11]. Off-label medical use was widespread in many surgical specialties and dentistry by the 1980's especially throughout Europe.

Concerns of tissue toxicity eventually excluded methyl 2-cyanoacrylate from use on human tissue [12]. Larger molecular weight monomers, such as the 2-octyl cyanoacrylate formulation used in Dermabond, have proven to be less histotoxic. Polymerized cyanoacrylate degrades into substances such as cyanoacetate and formaldehyde that may produce skin inflammation if accumulated

${ }^{\star}$ Correspondence to: Justin Gorski, Department of Obstetrics, Gynaecology and Reproductive Science Icahn School of Medicine at Mount Sinai New York, New York, USA, Tel: +1-716-909-9133, E-mail: justin.gorski@mountsinai.org

Key words: gynaecology, allergic reaction, Dermabond

Received: May 07, 2018; Accepted: May 23, 2018; Published: May 28, 2018 
in surrounding tissue [13]. Longer-chained cyanoacrylates, such as the 2-octyl cyanoacrylate monomer present in Dermabond, releases less degradation products than the short-chained monomers thus producing less potential histotoxicity. 2-octyl cyanoacrylate should slough off naturally with desquamation of the epidermis 7-14 days after application [14].

Although rare, cases of allergic contact dermatitis secondary to 2-octyl cyanoacrylate have been reported in the literature. However, there has never been a reported case resulting from use during gynaecologic surgery until now. Here we report a case of allergic reaction secondary to use of Dermabond at Mount Sinai Hospital in New York, NY.

\section{Case presentation}

A 63-year-old nulliparous female presented on post-operative day 7 status post total laparoscopic hysterectomy and bilateral salpingooophorectomy with sudden onset of erythema and pruritus around all four port site incisions (Figure 1).

The surgical course a week before was uncomplicated. Intraoperatively, Veress needle entry was made into the abdominal cavity and a $5 \mathrm{~mm}$ trocar with scope was placed to visualize the abdominal cavity. Three additional trocars were placed in the right lower quadrant, left lower quadrant and at the umbilicus. The uterus was removed and then the vaginal cuff was closed with 0 -vicryl suture. The trocars were removed, fascia closed with 0 -vicryl suture and the skin edges were approximated and closed with two thin layers of Dermabond.

Past medical history is significant for stage 0 DCIS, chronic hypertension and migraine headache. Last menstrual period occurred at 42 years old. Surgical history is significant for partial left mastectomy performed two years prior and L5 laminectomy fifteen years before presentation. Anaphylactic allergic reaction, throat closure and systemic pruritus, has been noted following exposure to aspirin and codeine approximately 20 years prior. No history of previous extended contact with acrylate glues, such as Superglue, artificial nail or eyelash adhesives or dental treatment requiring use of adhesives.

Physical examination of the surgical incision sites revealed that they were all clean dry and intact. A thin layer of Dermabond remained in place on the epidermis and an erythematous raised wheal with a radius of $1-3 \mathrm{~cm}$ surrounded each incision (Figure 2).

\section{Investigations}

Not Applicable

\section{Differential diagnosis}

Surgical site infection should always be considered when evaluating a potential allergic reaction to Dermabond or other skin adhesive.

\section{Treatment}

The patient was advised to remove the remaining skin adhesive with petroleum jelly and acetone per the manufacturer's instruction and referred to a dermatologist. Subsequent dermatologic evaluation confirmed the suspicion of an allergic reaction to Dermabond. The dermatologist made recommendation to apply a thin topical layer of hydrocortisone $1 \%$ to affected areas two to four times per day.

\section{Outcome and follow-up}

Skin inflammation and pruritus abated completely within two days. Skin patch testing performed three years after initial presentation was positive for ethyl cyanoacrylate.

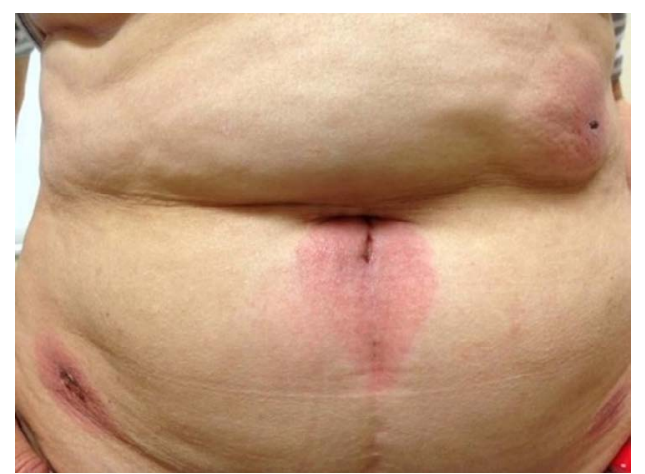

Figure 1. Abdomen of 63-year-old patient on post-operative day 7 with sudden onset erythema and pruritus surrounding the umbilical, left upper abdominal, left lower abdominal and right lower abdominal 5-mm trocar sites

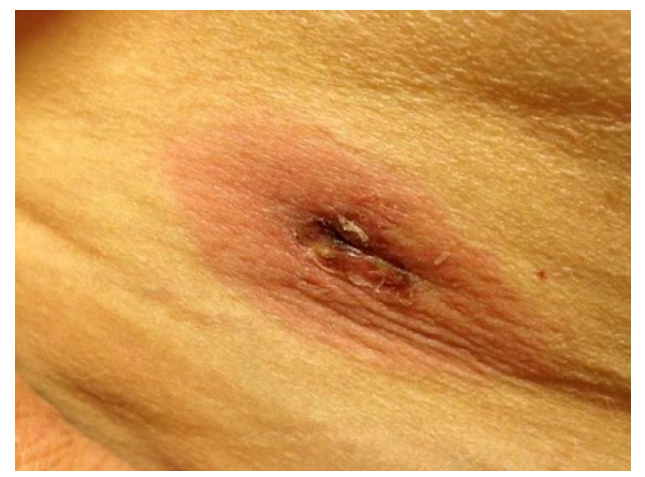

Figure 2. Close-up view of erythema surrounding the right lower abdominal 5-mm trocar site on post-operative day 7

\section{Discussion}

Although there are only a few surgical cases reported regarding allergic reaction to topical application of 2-octyl cyanoacrylate, the current literature is rife with allergic reaction to other cyanoacrylate formulations especially when used during previous surgeries as outlined (Table 1) [13,15-24].

Our case, and the cases reviewed here, highlight the usual temporal presentation of allergic reaction to Dermabond. Pruritus will begin at the incision sites around post-operative day 3 and continue until development of visually apparent erythematous wheals surrounding each site around post-operative day 7.

Reports have also described allergic contact dermatitis following application of cyanoacrylate-containing false eyelash glue $[25,26]$. Work as a cosmetician with regular exposure to cyanoacrylate-based eyelash extension glue has also been linked to occupational asthma and allergic rhinitis [27]. Occupational asthma has also been linked to exposure to cyanoacrylate adhesives used to affix sculpted acrylic artificial nails in beauty salons [28]. Extensive exposure to these sources of cyanoacrylate adhesives should be investigated before the decision is made to use Dermabond for surgical skin closure as they may predispose the patient to allergic reaction.

\section{Learning points/take home messages}

- The use of Dermabond as the first choice for closing surgical wounds will only increase with the increasing number of gynaecologic surgeries being performed robotically and laparoscopically.

- The potential adverse effects resulting from use of Dermabond should be discussed with every patient before use. 
Table 1. Published reports of an allergic reaction to Dermabond

\begin{tabular}{|c|c|c|c|c|c|}
\hline Field & Age (years) & $\begin{array}{l}\text { Time elapsed from surgery } \\
\text { to onset of allergic reaction } \\
\text { (days) }\end{array}$ & $\begin{array}{l}\text { Previous history of } \\
\text { cyanoacrylate use }\end{array}$ & Confirmatory Testing & Publication \\
\hline Orthopedic Surgery & 66 & 28 & None & Dermabond D2++/D4+++ & El-Dars, et al. 2010 \\
\hline Orthopedic Surgery & $12,14,16$ & $2-3,7-14$ & $\begin{array}{l}\text { Unreported; each with 1-3 } \\
\text { prior orthopedic surgeries }\end{array}$ & Dermabond D2+++/D4+++ & Gonzalo-Garijo, et al. 2009 \\
\hline $\begin{array}{l}\text { Plastic Surgery } \\
\text { (abdominoplasty) }\end{array}$ & 32 & 7 & Unreported & Dermabond Positive & Hivnor, et al. 2008 \\
\hline $\begin{array}{c}\text { Plastic Surgery (breast } \\
\text { augmentation) }\end{array}$ & 36 & 3 & $\begin{array}{l}\text { Yes, 1-year prior for tubal } \\
\text { ligation with haphazard } \\
\text { application and prolonged } \\
\text { embedded application }\end{array}$ & Unknown & Perry, et al. 2009 \\
\hline $\begin{array}{c}\text { Plastic Surgery (breast } \\
\text { augmentation) }\end{array}$ & 44 & 10 & Unreported & $\begin{array}{c}\text { Octyl-2 cyanoacrylate and } \\
\text { Prineo self-adhering mesh }++\end{array}$ & Dunst, et al. 2010 \\
\hline Plastic Surgery & 49 & 3 & Unreported & Dermabond +++ & Sachse, et al. 2013 \\
\hline Orthopedic Surgery & 50,41 & 21,3 & Yes, with acrylic nails, Yes & $\begin{array}{c}\text { Dermabond \& } \\
\text { 2-hydroxyethyl methacrylate } \\
+++, \text { Dermabond \& N-2- } \\
\text { butyl cyanoacrylate }+++\end{array}$ & McDonald \& Buckley 2014 \\
\hline Breast Surgery & $35,39,61$ & 8,5 & Yes, for all & None & Caton \& Dauphine 2014 \\
\hline Breast Surgery & 55 & 7 & Unreported & None & Ricci, et al. 2014 \\
\hline $\begin{array}{c}\text { Neurosurgery, Laparoscopic } \\
\text { General Surgery }\end{array}$ & $33,65,35,44$ & $7,7,7$ & $\begin{array}{c}\text { None for first case } \& \text { yes for } \\
\text { other } 3 \text { cases }\end{array}$ & $\begin{array}{c}\text { 2-octyl cyanoacrylate }++ \\
\&+++\end{array}$ & Bowen, et al. 2014 \\
\hline Orthopedic Surgery & 30 & 1 & Unreported & $\begin{array}{c}\text { Dermabond, Dermabond with } \\
\text { chlorhexidine, and } \\
\text { Dermabond with povidone } \\
\text { iodine }+++\end{array}$ & Lefevre, et al. 2016 \\
\hline
\end{tabular}

- Care should be taken to apply Dermabond in thin layers to the edges of apposed skin with minimal seepage into the wound cavity.

- Surgical site infection should always be considered when evaluating a potential allergic reaction to Dermabond or other skin adhesive.

- If an allergic reaction is encountered, Dermabond should be removed with petroleum jelly or acetone. Inflamed skin should be treated with hydrocortisone $1 \%$ applied topically two to four times per day until reaction abates.

- Skin patch testing can be utilized to confirm clinical suspicion for an allergic reaction to Dermabond.

\section{Patient's perspective}

Not applicable.

\section{References}

1. Wright JD, Herzog TJ, Tsui J, Ananth CV, Lewin SN, et al. (2013) Nationwide trends in the performance of inpatient hysterectomy in the United States. Obstet Gynecol 122: 233-241. [Crossref]

2. Wright JD, Ananth CV, Lewin SN, Burke WM, Lu YS, et al. (2013) Robotically assisted vs laparoscopic hysterectomy among women with benign gynaecologic disease. JAMA 20: 689-698. [Crossref]

3. Ethicon Inc. (2011) Dermabond Advanced - Topical Skin Adhesive: Instructions for Use, San Lorenzo, Puerto Rico.

4. Dermabond (1998) FDA, Summary of Safety and Effectiveness Data, Device Generic Name: Tissue Adhesive, Device

5. Moschos M, Droutsas D, Boussalis P, Tsioulias G (1997) Clinical experience with cyanoacrylate tissue adhesive. Documenta Ophthalmologica 93: 237-245. [Crossref]

6. Quinn JV (2005) Tissue Adhesives in Clinical Medicine. 2nd ed. Hamilton, Canada.

7. Singer AJ, Quinn JV, Hollander JE (2008) The cyanoacrylate topical skin adhesives. Am J Emerg Med 26: 490-496. [Crossref]

8. Ardis AE (1949) US patent nos. 2467926 and 2467927.

9. Coover HW, Joyner FB, Shearer NH, Wicker TH (1959) Chemistry and performance of cyanoacrylate adhesives. SPE Tech Papers 5: 92.
10. Hayes, Sharon Caskey (2004) Discovery of Super Glue helped land Coover in National Inventors Hall of Fame," Kingsport Times-News.

11. Webster RG Jr, Slansky HH, Refojo MF, Boruchoff SA, Dohlman CH (1968) The use of adhesive for the closure of corneal perforations. Report of two cases. Arch Ophthalmol 80: 705-709. [Crossref]

12. Ronis ML, Harwich JD, Fung R, Dellavecchia M (1984) Review of cyanoacrylate tissue glues with emphasis on their otorhinolaryngological applications. The Laryngoscope 94: 210-213. [Crossref]

13. El-Dars LD, Chaudhury W, Hughes TM, Stone NM (2010) Allergic contact dermatitis to Dermabond after orthopaedic joint replacement. Contact Dermatitis 62: 315-317.

14. Seo JH, Lee DH (2008) Patient satisfaction with a tissue adhesive in preauricular fistulectomy. Wounds 20: 284-289. [Crossref]

15. Gonzalo-Garijo MA, Perez-Calderon R, Perez-Rangel I, Sanchez-Vega S, Constantino JA (2009) Contact dermatitis after orthopaedic surgery. Contact Dermatitis 61: 299300. [Crossref]

16. Hivnor CM, Hudkins ML (2008) Allergic contact dermatitis after postsurgical repair with 2-octylcyanoacrylate. Arch Dermatol 144: 814-815. [Crossref]

17. Perry AW, Sosin M (2009) Severe allergic reaction to Dermabond. Aesthet Surg J 29 314-316. [Crossref]

18. Dunst KM, Auboeck J, Zahel B, Raffier B, Huemer GM (2010) Extensive allergic reaction to a new wound closure device (Prineo). Allergy 65: 798-799. [Crossref]

19. Sachse MM, Junghans T, Rose C, Wagner G (2013) Allergic contact dermatitis caused by topical 2-octyl-cyanoacrylate. Contact Dermatitis 68: 317-319.

20. Mc Donald BS, Buckley DA (2014) Severe dermatitis from Dermabond ${ }^{\circledR}$ surgical glue. Br J Dermatol 170: 739-741. [Crossref]

21. Caton AM, Dauphine C (2014) Allergic contact dermatitis after repeated exposure to Dermabond $^{\mathrm{TM}}$. Am Surg 80: 520-522. [Crossref]

22. Ricci JA, Parekh NN, Desai NS (2014) Diffuse cutaneous allergic reaction to Dermabond. Prehosp Disaster Med 29: 546-548. [Crossref]

23. Bowen, C, Bidinger J, Hivnor C, Hoover A, Henning J (2014) Allergic contact dermatitis to 2-Octyl cyanoacrylate. Cutis 94: 183-186. [Crossref]

24. Lefèvre S, Valois A, Truchetet F (2016) Allergic contact dermatitis caused by Dermabond (®). Contact Dermatitis 75: 240-241. [Crossref]

25. Shanmugam S, Wilkinson M (2012) Allergic contact dermatitis caused by a cyanoacrylate-containing false eyelash glue Contact Dermatitis 67: 309-310. [Crossref] 
26. Bhargava K, White JM, White IR (2012) Eyelid allergic contact dermatitis caused by ethyl cyanoacrylate-containing eyelash adhesive. Contact Dermatitis 67: 306-307. [Crossref]

27. Lindstrom I, Suojalehto H, Henriks-Eckerman ML, Suuronen K (2013) Occupational asthma and rhinitis caused by cyanoacrylate-based eyelash extension glues Occup Med 63: 294-297. [Crossref]
28. Jurado-Palomo J, Caballero T, Fernández-Nieto M, Quirce S (2009) Occupational asthma caused by artificial cyanoacrylate fingernails. Ann Allergy Asthma Immunol 102: 440-441. [Crossref]

Copyright: (C2018 Gorski J. This is an open-access article distributed under the terms of the Creative Commons Attribution License, which permits unrestricted use, distribution, and reproduction in any medium, provided the original author and source are credited. 